\title{
Peningkatan Kualitas Permukiman Melalui Program Kotaku Di Kelurahan Muara Bulian
}

\author{
Rioni Rizki Aldiansyah \\ Fakultas Teknik Universitas Batanghari Jambi \\ Correspondence email: rioni.rizki.aldiansyah@unbari.ac.id
}

\begin{abstract}
Abstrak. Kabupaten Batanghari merupakan kabupaten yang memiliki permasalahan permukiman kumuh. Dalam rangka menjaga dan meningkatkan kualitas permukiman di kabupaten Batanghari Dirjen Cipta Karya melalui Balai Prasarana Permukiman Wilayah Jambi menetapkan lokasi Kelurahan Muara Bulian kabupaten Batanghari menjadi lokasi BPM Program Kotaku tahun 2020. Untuk menjaga kualitas permukiman di kelurahan Muara Bulian maka dibutuhkan suatu permukiman yang terencana, sistematis dan berkelanjutan. Hal ini akan tercapai dengan menerapkan prinsip perencanaan yang cepat, tepat, efektif dan efisien dalam pembangunan infrastruktur permukiman. Penelitian ini difokuskan pada lokasi yang dianggap kumuh Sesuai dengan SK Bupati Kabupaten Batanghari No.110 Tahun 2019 tentang penetapan lokasi lingkungan perumahan dan permukiman kumuh di kelurahan muara bulian kabupaten Batanghari seluas 11,0 7 Ha. Empat kategori kekumuhan ditetapkan menurut panduan Dirjen Cipta Karya yaitu: tidak kumuh (0-19), kumuh ringan (19-44), kumuh sedang (45-70) dan kumuh berat (71-95). Kekumuhan ditentukan berdasarkan 7 (tujuh) Indikator yang merupakanmenjadi faktor fisik meliputi kondisi bangunan gedung, jalan lingkungan, penyediaan air minum, drainase lingkungan, pengelolaan air limbah, pengelolaan persampahan, dan proteksi kebakaran. Faktor non fisik berupa sosial dan ekonomi juga menjadi acuan dalam penilaian ini kemudian menlihat hasil investasi dari kegiatan kotaku yang sudah dikerjakan pada tahun 2020. Hasil penelitian menunjukkan lokasi Kelurahan Muara Bulian pada total 37 RT mempunyai nilai 9 masuk kriteria kawasan tidak kumuh tetapi dirunut berdasarkan data per RT maka dapat disimpulkan ada 13 RT dengan katagori kumuh Ringan dan 1 RT dengan katagori kumuh sedang. faktor fisik dan non fisik dalam sangat berpengaruh terhadap tingkat kekumuhan di kelurahan Muara Bulian Kabupaten Batanghari. Dana BPM Program Kotaku tahun 2020 hanya melakukan investasi pengurungan kumuh pada 3 lokasi RT saja yaitu pada RT031 dengan nilai Kumuh Ringan memberikan kontribusi penanganan sebesar 18,55 \%, RT003 Kumuh Ringan memberikan kontribusi penanganan sebesar 13,59 $\%$, dan RT006 Kumuh Sedang memberikan kontribusi penanganan sebesar 0,69\%. Dalam hal ini kegiatan investasi pengurangan kumuh pada tahun 2020 dilakukan dengan pekerjaan pembuatan jalan rigid beton sepanjang 1145 Meter.
\end{abstract}

Kata kunci: Permukiman Kumuh; Program Kotaku; Batanghari

\section{PENDAHULUAN}

Kelurahan Muara Bulian merupakan ibukota Kabupaten Batanghari dengan luas area kumuh menurut SK Bupati Kabupaten Batanghari No.110 Tahun 2019 seluas 11,07 Ha. Dengan jumlah Bangunan 1705 Unit, Jumlah Penduduk 6818 Jiwa dan Jumlah Kepala Keluarga 1820 KK (Baseline Kotaku, 2020). Menurut data Batanghari dalam angka tahun 2019 mayoritas penduduk khususnya di kelurahan muara bulian bekerja di sektor industri, perdagangan dan pertaninan. Muara Bulian juga merupakan kelurahan dengan jumlah penduduk terbanyak kedua setelah kelurahan rengas condong (BPS Kabupaten Batanghari, 2019). Banyaknya penduduk ternyata tidak seimbang dengan kesadaran masyarakat dalam meningkatkan kualitas permukiman kumuh di daerah perkotaan. Terbukti sesuai dengan hasil pengumpulan data baseline tim fasilitator kelurahan program kotaku masalah yang muncul pada kelurahan muara bulian dilihat dari sisi kualitas permukiman adalah tidak terjangkaunya masyarakat berpenghailan rendah (MBR) dalam pemenuhan rumah layak huni, drainase terputus dan belum melayani seluruh kawasan mengakibatkan sering terjadi genangan di depan rumah, rawan bencana banjir dan genangan, berada di kawasan bantaran sungai sehingga rawan banjir, pelayanan air bersih, persampahan dan sanitasi masih kurang (sanitasi resiko tinggi), tidak berfungsinya MCK yang dibangun oleh pemerintah karena ketidak tersediaan air bersih, dan belum adanya lampu penerangan di tiap-tiap dusun serta kurang layaknya rumah KK miskin.

Untuk menigkatkan kualitas permukiman pada kelurahan muara bulian ini, maka perlu strategi khusus untuk membuat suatu perencanaan yang sistematis serta menerapkan perencanaan yang tepat, efektif dan efisien dalam pembangunan infrastruktur permukiman sesuai dengan kebutuhan masyarakat pada lokasi permukiman kumuh. Tujuan dari penelitian ini adalah mengetahui besarnya faktor fisik dan non fisik dalam pengaruhnya terhadap tingkat kekumuhan penduduk di kelurahan muara bulian kabupaten Batanghari dan melihat hasil investasi dari kegiatan kotaku yang sudah dikerjakan pada tahun 2020.

Berbagai kebijakan dan peraturan pemerintah yang berkaitan dengan perumahan dan permukiman dituangkan dalam banyak sekali dokumen, diantaranya adalah:

1. Undang Undang Republik Indonesia Nomor 1 Tahun 2011 Tentang Perumahan dan Kawasan Permukiman

2. Undang Undang Republik Indonesia Nomor 4 Tahun 1992 Tentang Perumahan dan Permukiman

3. Peraturan Menteri Pekerjaan Umum dan Perumahan Rakyat Republik Indonesia Nomor 14/PRT/M/2018 Tentang Penegahan dan Peningkatan Kualitas Terhadap Perumahan Kumuh dan Permukiman Kumuh. 
4. Keputusan Menteri Permukiman dan Prasarana Wilayah Republik Indonesia Nomor 217/KPTS/M/2002 Tentang Pedoman Umum Peningkatan Kualitas Permukiman.

5. Keputusan Bupati Batanghari Nomor: 110 Tahun 2019 Tentang Penetapan Lokasi Lingkungan Perumahan dan Permukiman Kumuh Di Kabupaten Batanghari

\section{METODE}

Tahapan pada penelitian ini dilakukan melalui kerjasama tim fasilitator kotaku, instansi terkait di kelurahan muara bulian kabupaten Batanghari dengan peneliti, untuk pemenuhan data panelitian. Objek pada penelitian ini adalah kelurahan muara bulian yang telah diberikan surat keputusan bupati Batanghari sebagai lokasi permukiman kumuh. Metode pegumpulan data penelitian ini menggunakan metode deskriptif-normatif.

Metode penelitian deskriptif dalam mengumpulkan data dapat dilakukan dengan menggunakan teknik wawancara dan observasi lapangan. Pendekatan normatif dilakukan dengan mengikuti aturan atau pedoman yang telah ditetapkan oleh Pemerintah sebagai standar dan landasan hukum. Metode Analisa data sesuai dengan kriteria perumahan kumuh dan permukiman kumuh Permen Pu No.14 Tahun 2018.

Analisis masalah dan potensi sarana dan prasarana guna peningkatan kualitas lingkungan permukiman menuju kota tanpa kumuh. Dengan memperhatikan 7 indikator kumuh. 1) Kondisi Bangunan Gedung, 2) Aksesibiltas Lingkungan, 3) Kondisi Pengelolaan Air Limbah, 4) Kondisi Saluran Drainase dan Genangan/Banjir, 5) Kondisi Pengelolaan Air Limbah, 6) Kondisi Pengelolaan Sampah, 7) Kondisi Penanganan Proteksi Kebakaran. Selanjutnya dari data yang telah diperoleh kita melakukan rencana teknis penanganan masalah-masalah yang ada dipermukiman kumuh untuk dilakukan penanganan peningkatan kualitas lingkungan permukiman guna menghilangkan masalah atau kekumuhan yang ada di wilayah sesuai dengan kondisi dilapangan. Sehingga mendapatkan perhitungan nilai kekumuhan akhir setelah dilakukan peningkatan kualitas.

Dari hasil pengumpulan dan pengolahan data, prosedur berikutnya adalah melakukan identifikasi dan pengukuran data yang sangat berguna untuk analisis data. Pengukuran kondisi lapangan menggunakan panduan yang sudah ditetapkan sesuai dengan Permen Pu No.14 Tahun 2018. Empat kategori kekumuhan ditetapkan dalam panduan ini yaitu: tidak kumuh (0-19), kumuh ringan (19-44), kumuh sedang (45-70) dan kumuh berat (71- 95). Masingmasing kategori akan diberi penilaian berturut-turut $0,1,3$ dan 5 untuk tidak kumuh, kumuh ringan, kumuh sedang dan kumuh berat.

Proses pendataan dilakukan melalui perlibatan instansi terkait yaitu Kelurahan Muara Bulian, Kecamatan Muara Bulian, Dinas Perkim Kabupaten Batanghari dan Kelembagaan masyarakat yang sudah dibentuk Badan Keswadayaan Masyarakat (BKM) dan Kelompok Swadaya Masyarakat (KSM). Partisipasi masyarakat dalam pendataan dilakukan dengan menggunakan sebaran format isian yang sudah disiapkan kepada masing-masing rumah tangga di 37 RT Kelurahan Muara Bulian atas Kerjasama pihak BKM, Ketua RT dan Fasilitator Kotaku. Setelah format isian disebarkan, maka selanjutnya dilakukan proses pengumpulan format isian tersebut secara berjenjang kepada pihak BKM dan dilakukan rekapitulasi, dimasukan kedalam format rumusan perhitungan numerik kumuh (R0) dapat dilihat pada tabel 1.

Data primer didapatkan melalui kunjungan secara langsung ke lokasi penelitian, dan merekam melalui foto-foto pada 7 indikator yang sudah ditetapkan serta mendata hasil investasi kegiatan kotaku pada tahun 2020. Wawancara dilakukan terhadap responden RT dan RW di lokasi penelitian sesuai dengan kebutuhan penelitian. Data skunder dalam penelitian ini ialah peta RTRW Kelurahan Muara Bulian, perda yang terkait dengan permukiman dan data BPS di Kabupaten Batanghari. 
Tabel 1. Rumusan Perhitungan Numerik Kumuh

\begin{tabular}{|c|c|c|c|}
\hline 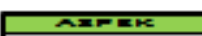 & 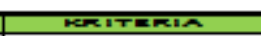 & 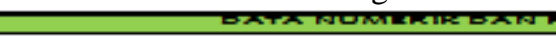 & 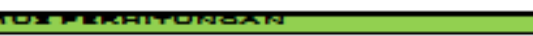 \\
\hline \multirow{3}{*}{ 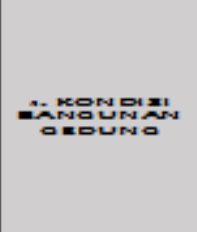 } & 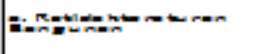 & 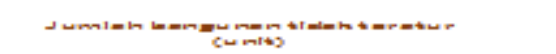 & 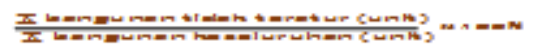 \\
\hline & 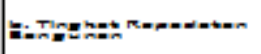 & 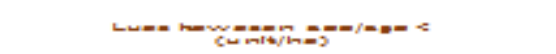 & 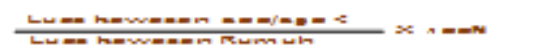 \\
\hline & 6:man & 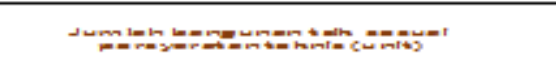 & 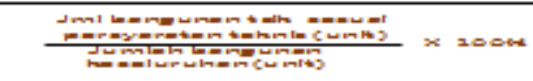 \\
\hline \multirow{2}{*}{ 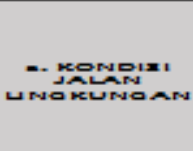 } & 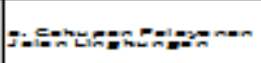 & 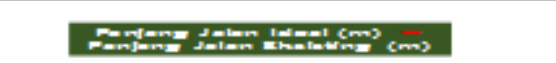 & 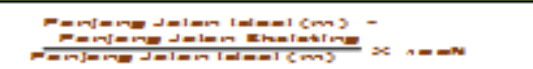 \\
\hline & $=0$ & 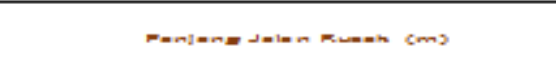 & 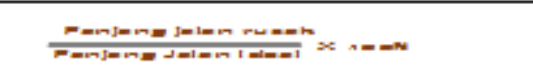 \\
\hline \multirow{2}{*}{ 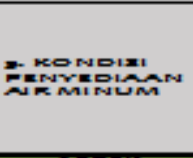 } & 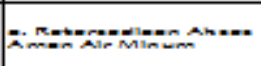 & 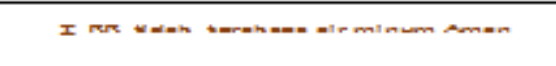 & 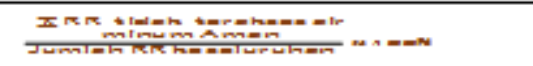 \\
\hline & int & 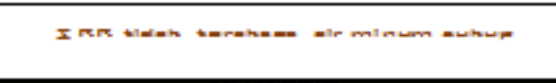 & 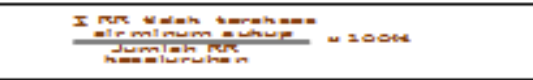 \\
\hline \multirow{5}{*}{ 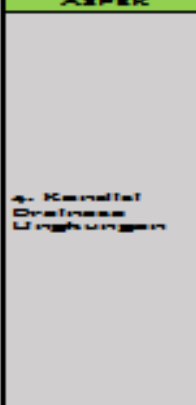 } & $\min _{\lim }$ & 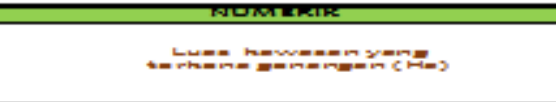 & 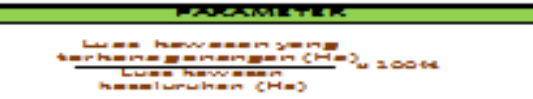 \\
\hline & $E \rightarrow$ & 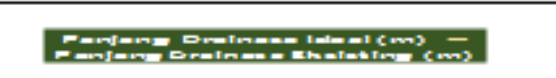 & 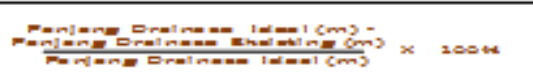 \\
\hline & 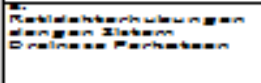 & 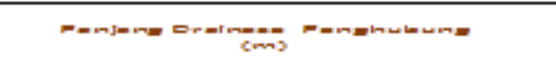 & 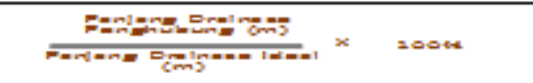 \\
\hline & 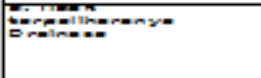 & 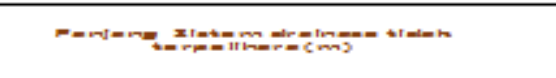 & 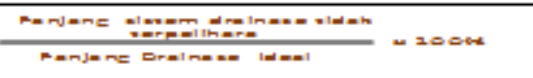 \\
\hline & 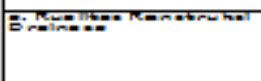 & 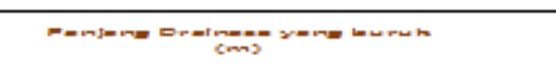 & 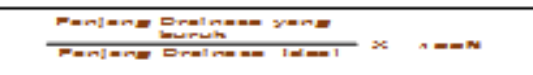 \\
\hline \multirow{2}{*}{$==2+1-n-m$} & 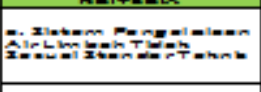 & 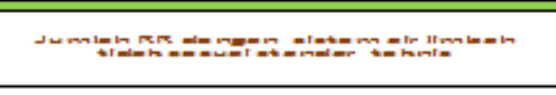 & 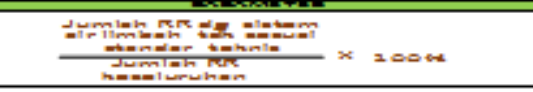 \\
\hline & 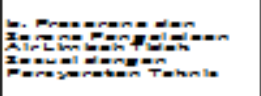 & 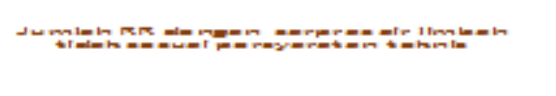 & 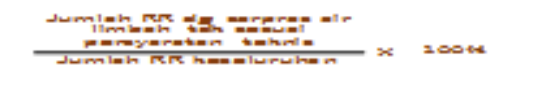 \\
\hline \multirow{3}{*}{$\because=2$} & 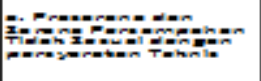 & دаminn & 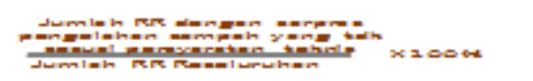 \\
\hline & 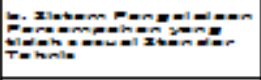 & r & 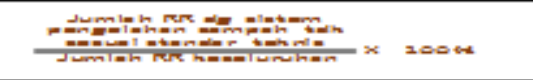 \\
\hline & 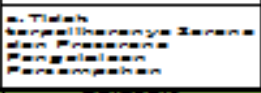 & 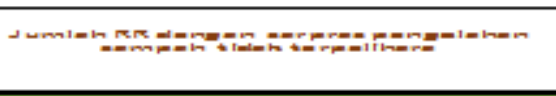 & 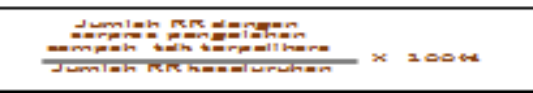 \\
\hline \multirow{2}{*}{$=-\infty$} & 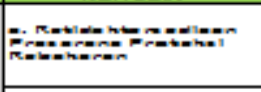 & 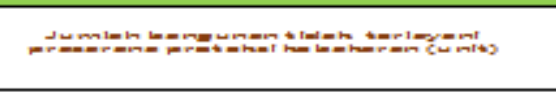 & 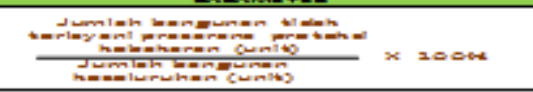 \\
\hline & 竞: & 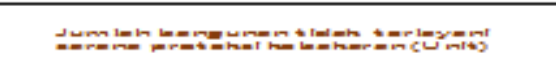 & 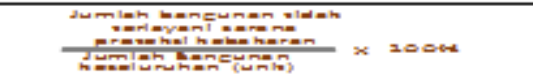 \\
\hline
\end{tabular}

\section{HASIL DAN PEMBAHASAN \\ Lokasi Penelitian}

Penelitian ini dilaksanakan dengan mengambil lokasi di kelurahan muara bulian, kecamatan muara bulian kabupaten Batanghari. Secara administratif kelurahan muara bulian mempunyai luas wilayah 1.820 Ha Dengan jumlah Bangunan 1705 Unit, Jumlah Penduduk 6818 Jiwa dan Jumlah Kepala Keluarga 1820 Orang. Mayoritas penduduk bekerja di industri, perdagangan dan pertaninan. Mengacu pada Rencana pembangunan jangka menengah daerah (RPJMD) Kabupaten Batanghari Tahun 2016-2021.

Secara geografi, wilayah Kabupaten Batang Hari terletak di bagian tengah Provinsi Jambi dengan luas wilayah 5.180,35 KM2 dan merupakan salah satu kabupaten di antara sebelas Kabupaten/Kota dalam Provinsi Jambi. Pemerintah Kabupaten Batang Hari dibentuk berdasarkan Peraturan Komisaris Pemerintah Pusat di Bukit Tinggi Nomor 81/Kom/U, tanggal 30 Nopember 1948 dengan pusat pemerintahan saat ini di Kota Muara Bulian berjarak sekitar 64 KM dari Kota Jambi. Secara administrasi wilayah Kabupaten Batang Hari terdiri dari delapan Kecamatan, 14 Kelurahan, 110 Desa dan 1.280 Rukun Tetangga (RT) dengan batas-batas wilayah sebagai berikut:

1. Sebelah Utara $\quad$ : Berbatasan dengan Kabupaten Tanjung Jabung Barat dan Kabupaten Muara Jambi

2. Sebelah Selatan : Berbatasan dengan Kabupaten Sarolangun, Kabupaten Muara Jambi dan Provinsi Sumatera Selatan 
3. Sebelah Timur : Berbatasan dengan Kabupaten Muaro Jambi

4. Sebelah Barat : Berbatasan dengan Kabupaten Muaro Jambi

Peta administrasi wilayah kabupaten disajikan pada Gambar 1.

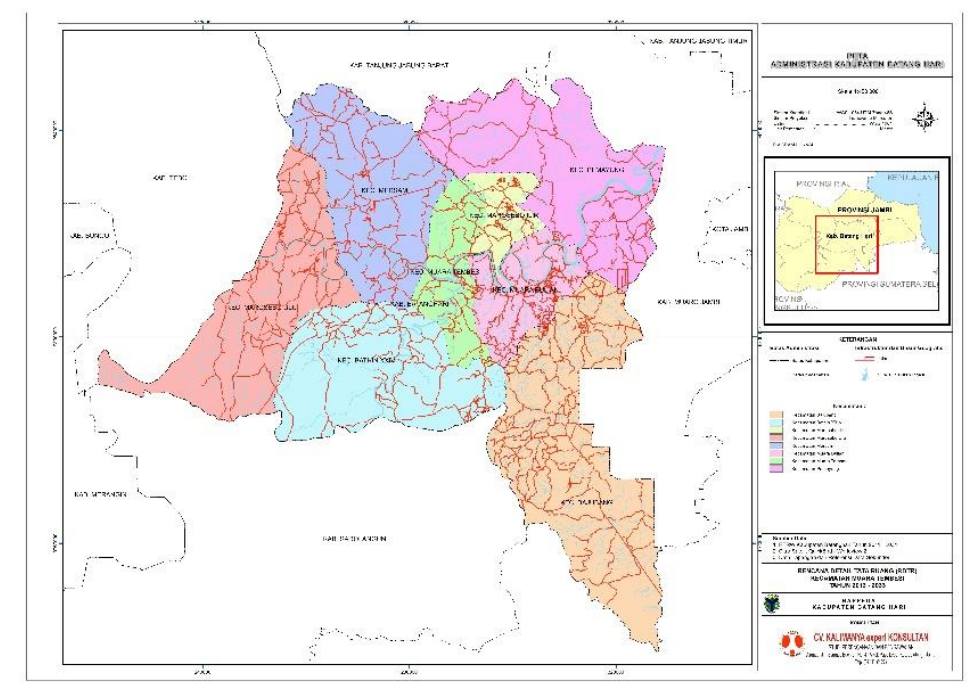

Sumber : Bappeda Batanghari, 2020

Gambar 1. Peta Administrasi Kabupaten Batanghari

\section{Analisis Faktor Fisik dan Faktor Non Fisik}

Dalam melakukan analisis faktor fisik berdasarkan Permen PU PR No.14 Tahun 2018 ada 7 (Tujuh) indikator, meliputi kondisi : bangunan gedung, jalan lingkungan, penyediaan air minum, drainase lingkungan, pengelolaan air limbah, pengelolaan persampahan, dan proteksi kebakaran.

Sedangkan kondisi non fisik disini meliputi kondisi lapangan sesuai dengan hasil survey pengamatan secara langsung tentang kondisi sosial dan ekonomi. Dari kondisi fisik dan non fisik dibuat penilaian kriteria yang dapat disajikan dalam bentuk tabel yang disajikan pada Tabel 1 .

Dari Tabel 3.1 terlihat total nilai berdasarkan variabel penilaian sebesar 9 yang menunjukkan bahwa kelurahan muara bulian kategori tidak kumuh . Dapat juga terlihat dari hasil variabel dalam bentuk persentase pada Gambar 3.1. Hasil perhitungan numerik kumuh sesuai dengan data baseline yang sudah direkapitulasi adalah nilai ketidakteraturan bangunan 3, sistem pengelolaan persampahan tidak yang tidak sesuai standar teknis 1, ketidaktersediaan sarana proteksi kebakaran 5. Tetapi dirunut berdasarkan data per RT pada tabel 3.2 maka dapat disimpulkan ada 13 RT dengan katagori kumuh ringan dan 1 RT dengan katagori kumuh sedang.

\section{Skenario Peningkatan Kualitas Lingkungan Permukiman Kumuh Tahun 2020}

Penetapan lokasi kumuh berdasrakan hasil data baseline yang sudah divalidasi dengan numerik kekumuhan. Lokasi kumuh tersebut juga sudah tertuang pada SK Bupati Batanghari nomor 110 Tahun 2019. Sesuai dengan sumber data dan hasil survey lapangan yang sudah dilaksanakan, maka pada tahun 2020 sudah dilakukan penguruangan kumuh melalui dana Bantuan Pemerintah untuk Masyarakat (BPM) melalui program kotaku tahun anggaran 2020 untuk kriteria jalan lingkungan. Dasar kegiatan adalah Keputusan Menteri (Kepmen) Penetapan lokasi dan besaran bantuan kegiatan infrastruktur berbasis masyarakat tahun anggaran 2020 nomor 167/KPTS/M/2020 melalu program Kotaku.

Penentuan lokasi kegiatan untuk pengurangan kumuh juga tergantung kebutuhan masyarakat dan kesiapan lahan untuk dilakukan investasi kegiatan pengurangan kumuh. Pada tahun 2020 yang sudah dilaksanakan melalui dana BPM Program Kotaku adalah pekerjaan pembuatan jalan rigid beton pada lokasi RT031, RT003, dan RT006 dimana nilai numerik kekumuhan pada lokasi tersebut adalah RT031 dengan nilai kumuh ringan, RT003 kumuh ringan dan RT031 kumuh sedang. 
Tabel 2. Tingkat Kekumuhan Awal dari 7 Indikator Kumuh

\begin{tabular}{|c|c|c|c|c|c|c|c|}
\hline \multicolumn{8}{|c|}{ TINGKAT KEKUMUHAN AWAL } \\
\hline \multirow{5}{*}{$\begin{array}{l}\text { Provinsi } \\
\text { Kab/Kota } \\
\text { Kecamatan } \\
\text { Kawasan }\end{array}$} & \multirow{5}{*}{$\begin{array}{l}\text { : Jambi } \\
\text { : Batanghari } \\
\text { : Muara Buian } \\
\text { : Muara Bulian }\end{array}$} & & \multirow{5}{*}{\multicolumn{2}{|c|}{$\begin{array}{l}\text { Luas SK } \\
\text { Luas Verifikasi } \\
\text { Jumlah Bangunan } \\
\text { Jumlah Penduduk } \\
\text { Jumlah Bangunan }\end{array}$}} & & 82,89 & \multirow{5}{*}{$\begin{array}{l}\text { Ha } \\
\text { Ha } \\
\text { Unit } \\
\text { Jiwa } \\
\text { KK }\end{array}$} \\
\hline & & & & & & 82,89 & \\
\hline & & & & & & 1.705 & \\
\hline & & & & & & 6.820 & \\
\hline & & & & & & 1.820 & \\
\hline \multirow{2}{*}{ ASPEK } & \multirow{2}{*}{ KRITERIA } & \multirow{2}{*}{ PARAMETER } & & \multicolumn{4}{|c|}{ KONDISI AWAL (BASELINE) } \\
\hline & & & SKOR & NUMERIK & SATUAN & PROSEN (\%) & NILAI \\
\hline \multirow{9}{*}{$\begin{array}{l}\text { 1. KONDISI } \\
\text { BANGUNAN } \\
\text { GEDUNG }\end{array}$} & \multirow{3}{*}{$\begin{array}{l}\text { a. Ketidakteraturan } \\
\text { Bangunan }\end{array}$} & $\begin{array}{l}76 \%-100 \% \text { bangunan pada lokasi tidak } \\
\text { memiliki keteraturan }\end{array}$ & 5 & \multirow{3}{*}{$1.019,00$} & \multirow{3}{*}{ Unit } & \multirow{3}{*}{$59,77 \%$} & \multirow{3}{*}{3} \\
\hline & & $\begin{array}{l}1 \%-75 \% \text { bangunan pada lokasi tidak } \\
\text { memiliki keteraturan }\end{array}$ & 3 & & & & \\
\hline & & \begin{tabular}{l|}
$25 \%-50 \%$ bangunan pada lokasi tidak \\
memiliki keteraturan
\end{tabular} & $\mathbf{1}$ & & & & \\
\hline & & \begin{tabular}{|l|}
$76 \%-100 \%$ bangunan memiliki \\
kepadatan tidak sesuai ketentuan
\end{tabular} & 5 & & & $0.00 \%$ & \\
\hline & b. Kepadatan & $\begin{array}{l}51 \%-75 \% \text { bangunan memiliki } \\
\text { kepadatan tidak ses uai ketentuan }\end{array}$ & 3 & $\mathbf{O}$ & $\mathrm{Ha}$ & 0,000 & $\mathbf{O}$ \\
\hline & & $\begin{array}{l}\text { 25\%-50\% bangunan memiliki } \\
\text { kepadatan tidak sesuai ketentuan }\end{array}$ & 1 & & & & \\
\hline & & $\begin{array}{l}\text { 76\% - 100\% bangunan pada lokasi } \\
\text { tidak memenuhi persyaratan teknis }\end{array}$ & 5 & & & & \\
\hline & $\begin{array}{l}\text { C. Retidaksesuaian } \\
\text { dengan Persyaratan }\end{array}$ & \begin{tabular}{|l|}
$51 \%-75 \%$ bangunan pada lokasi tidak \\
memenuhi persyaratanteknis
\end{tabular} & $\mathbf{3}$ & 100,00 & Unit & $5,87 \%$ & O \\
\hline & Teknis Bangunan & $\begin{array}{l}25 \%-50 \% \text { bangunan pada lokasi tidak } \\
\text { memenuhi persyaratan teknis }\end{array}$ & 1 & & & & \\
\hline & & $\begin{array}{l}76 \%-100 \% \text { area tidak terlayani oleh } \\
\text { jaringanjalanlingkungan }\end{array}$ & 5 & & & $0,31 \%$ & \\
\hline & $\begin{array}{l}\text { a. Cakupan Pelayanan } \\
\text { Jalan Lingkungan }\end{array}$ & $\begin{array}{l}\text { 51\%-75\% area tidak terlayani oleh } \\
\text { jaringanjalan lingkungan }\end{array}$ & 3 & 100,00 & Meter & & $\mathbf{O}$ \\
\hline 2. Kondisi & & $\begin{array}{l}25 \%-50 \% \text { area tidak terlayani oleh } \\
\text { jaringanjalan lingkungan }\end{array}$ & $\mathbf{1}$ & & & & \\
\hline $\begin{array}{l}\text { Jalan } \\
\text { Lingkungan }\end{array}$ & & $\begin{array}{l}76 \%-100 \% \text { area memiliki kualitas } \\
\text { permukaan jalan yang buruk }\end{array}$ & 5 & & & $24,89 \%$ & \\
\hline & Permukaan Jalan & $\begin{array}{l}51 \%-75 \% \text { area memiliki kualitas } \\
\text { permukaan jalan yang buruk }\end{array}$ & 3 & $8.078,70$ & Meter & & $\mathbf{O}$ \\
\hline & lingkungan & $\begin{array}{l}25 \%-50 \% \text { area memiliki kualitas } \\
\text { permukaan jalan yang buruk }\end{array}$ & $\mathbf{1}$ & & & & \\
\hline & & $\begin{array}{l}\text { 76\%-100\% Populasi tidak dapat } \\
\text { mengakses air minum yang aman }\end{array}$ & 5 & & & $538 \%$ & \\
\hline Penyediaan & Akses Aman Air & $\begin{array}{l}51 \%-75 \% \text { Populasi tidak dapat } \\
\text { mengakses airminumyang aman }\end{array}$ & 3 & 98,00 & KK & $5,38 \%$ & o \\
\hline Air Minum & Minum & $\begin{array}{l}25 \%-50 \% \text { Populasi tidak dapat } \\
\text { mengakses air minum yang aman }\end{array}$ & 1 & & & & \\
\hline & b. Tidak & $\begin{array}{l}76 \%-100 \% \text { Populasi tidak terpenuhi } \\
\text { kebutuhan air minum minimalnya }\end{array}$ & 5 & & & & \\
\hline & terpenuhinya & $\begin{array}{l}51 \%-75 \% \text { Populasi tidak terpenuhi } \\
\text { kebutuhan airminum minimalnya }\end{array}$ & 3 & 71,00 & KK & $3,90 \%$ & o \\
\hline & & $\begin{array}{l}25 \%-50 \% \text { Populasi tidak terpenuhi } \\
\text { kebutuhan air minum minimalnya }\end{array}$ & $\mathbf{1}$ & & & & \\
\hline & a. Ketidakmampuan & $\begin{array}{l}76 \%-100 \% \text { area terjadi genangan }>30 \\
\mathrm{~cm},>2 \mathrm{jam}>2 \times \text { setahun }\end{array}$ & 5 & & & $6,48 \%$ & \\
\hline & Mengalirkan & \begin{tabular}{|l|}
$51 \%-75 \%$ area terjadi genangan $>30$ \\
$\mathrm{~cm},>2 \mathrm{jam}>2 \times$ setahun
\end{tabular} & 3 & 5,38 & $\mathrm{Ha}$ & & $\mathbf{O}$ \\
\hline & Limpasan Air & $\begin{array}{l}25 \%-50 \% \text { area terjadi genangan }>30 \\
\mathrm{~cm},>2 \mathrm{jam}>2 \times \text { setahun }\end{array}$ & $\mathbf{1}$ & & & & \\
\hline & & $\begin{array}{l}76 \%-100 \% \text { area tidak tersedia } \\
\text { drainaselingkungan }\end{array}$ & 5 & & & $3,27 \%$ & $\mathbf{O}$ \\
\hline 4. Kondisi & $\begin{array}{l}\text { b. Ketidaktersediaan } \\
\text { Drainase }\end{array}$ & $\begin{array}{l}51 \%-75 \% \text { area tidak tersedia } \\
\text { drainaselingkungan }\end{array}$ & 3 & 800,00 & Meter & & \\
\hline $\begin{array}{l}\text { Drainase } \\
\text { Lingkungan }\end{array}$ & & $\begin{array}{l}25 \%-50 \% \text { area tidak tersedia } \\
\text { drainase lingkungan }\end{array}$ & 1 & & & & \\
\hline & & $\begin{array}{l}76 \%-100 \% \text { area memiliki kualitas } \\
\text { konstruksi drainaselingkungan buruk }\end{array}$ & 5 & & & $24,71 \%$ & o \\
\hline & $\begin{array}{l}\text { e. Kualitas Konstruksi } \\
\text { Drainase }\end{array}$ & $\begin{array}{l}51 \%-75 \% \text { area memiliki kualitas } \\
\text { konstruksi drainaselingkungan buruk }\end{array}$ & 3 & $6.045,95$ & Meter & & \\
\hline & & $\begin{array}{l}25 \%-50 \% \text { area memiliki kualitas } \\
\text { konstruksi drainaselingkungan buruk }\end{array}$ & 1 & & & & \\
\hline & a. Sistem & $\begin{array}{l}76 \%-100 \% \text { area memiliki sistem air } \\
\text { limbah yang tidak sesuai standar } \\
\text { teknis }\end{array}$ & 5 & & & $9,51 \%$ & o \\
\hline & $\begin{array}{l}\text { a. Sistem } \\
\text { Pengelolaan Air } \\
\text { Limbah Tidak Sesuai }\end{array}$ & $\begin{array}{l}51 \%-75 \% \text { area memiliki sistem air } \\
\text { limbah yang tidak sesuai standar } \\
\text { teknis }\end{array}$ & 3 & 173,00 & KK & & \\
\hline 5. Kondisi & Standar Teknis & $\begin{array}{l}25 \%-50 \% \text { area memiliki sistem air } \\
\text { limbah yang tidak sesuai standar } \\
\text { teknis }\end{array}$ & $\mathbf{1}$ & & & & \\
\hline $\begin{array}{l}\text { Pengelolaan } \\
\text { Air Limbah }\end{array}$ & b. Prasarana dan & $\begin{array}{l}76 \%-100 \% \text { area memiliki sarpras air } \\
\text { limbah tidak sesuai dengan } \\
\text { persyaratan teknis }\end{array}$ & 5 & & & $12,91 \%$ & o \\
\hline & $\begin{array}{l}\text { Sarana Pengelolaan } \\
\text { Air Limbah Tidak } \\
\text { Sesuai dengan }\end{array}$ & $\begin{array}{l}51 \%-75 \% \text { area memiliki sarpras air } \\
\text { limbah tidak sesuai dengan } \\
\text { persyaratan teknis }\end{array}$ & 3 & 235,00 & KK & & \\
\hline & Persyaratan Teknis & $\begin{array}{l}25 \%-50 \% \text { area memiliki sarpras air } \\
\text { limbah tidak sesuai dengan } \\
\text { persyaratan teknis }\end{array}$ & 1 & & & & \\
\hline & & $\begin{array}{l}76 \%-100 \% \text { area memiliki sarpras } \\
\text { pengelolaan persampahan yang tidak } \\
\text { memenuhi persyaratan teknis }\end{array}$ & 5 & & & $19,95 \%$ & o \\
\hline & $\begin{array}{l}\text { a. Prasarana dan } \\
\text { Sarana Persampahan } \\
\text { Tidak Sesuai dengan }\end{array}$ & $\begin{array}{l}\text { 51\%-75\% area memiliki sarpras } \\
\text { pengelolaan persampahan yang tidak } \\
\text { memenuhi persyaratan teknis }\end{array}$ & 3 & 363,00 & KK & & \\
\hline $\begin{array}{l}\text { 6. Kondisi } \\
\text { Pengelolaan } \\
\text { Persampahan }\end{array}$ & persyaratan Teknis & $\begin{array}{l}25 \%-50 \% \text { area memiliki sarpras } \\
\text { pengelolaan persampahan yang tidak } \\
\text { memenuhi persyaratan teknis }\end{array}$ & $\mathbf{1}$ & & & & \\
\hline & b. Sistem & $\begin{array}{l}76 \%-100 \% \text { area memiliki sistem } \\
\text { persampahan tidak sesuai standar }\end{array}$ & 5 & & & $42,42 \%$ & 1 \\
\hline & $\begin{array}{l}\text { Pengelolaan } \\
\text { Persampahan yang }\end{array}$ & $\begin{array}{l}51 \%-75 \% \text { area memiliki sistem } \\
\text { persampahan tidak sesuai standar }\end{array}$ & 3 & 772,00 & KK & & \\
\hline & $\begin{array}{l}\text { tidak sesuai Standar } \\
\text { Teknis }\end{array}$ & $\begin{array}{l}25 \%-50 \% \text { area memiliki sistem } \\
\text { persampahan tidaksesuai standar }\end{array}$ & 1 & & & & \\
\hline & & $\begin{array}{l}76 \%-100 \% \text { area tidak memiliki } \\
\text { prasaranaproteksikebakaran }\end{array}$ & 5 & & & $1,99 \%$ & 0 \\
\hline & $\begin{array}{l}\text { a. Ketidaktersediaan } \\
\text { Prasarana Proteksi }\end{array}$ & $\begin{array}{l}51 \%-75 \% \text { area tidak memiliki } \\
\text { prasaranaproteksikebakaran }\end{array}$ & 3 & 34,00 & Unit & & \\
\hline 7. Kondisi & Kebakaran & \begin{tabular}{|l} 
prasarana proteksi kebakaran \\
$25 \%-50 \%$ area tidak memiliki
\end{tabular} & 1 & & & & \\
\hline Proteksi & & $\begin{array}{l}\text { prasarana proteksi kebakaran } \\
76 \%-100 \% \text { area tidak memiliki }\end{array}$ & 5 & & & & \\
\hline Kebakaran & & sarana proteksi kebakaran & 5 & & & $97,30 \%$ & 5 \\
\hline & Sarana Proteksi & $\begin{array}{l}51 \%-75 \% \text { area tidak memiliki sarana } \\
\text { proteksi kebakaran }\end{array}$ & 3 & $1.659,00$ & Unit & & \\
\hline & Kebakar & $\begin{array}{l}25 \%-50 \% \text { area tidak memiliki sarana } \\
\text { proteksi kebakaran }\end{array}$ & $\mathbf{1}$ & & & & \\
\hline & $\begin{array}{r}\text { BATAS AMBANG } \\
71-95\end{array}$ & $\begin{array}{l}\text { NILAI TING KAT KEKUMUHAN } \\
\text { KUMUH BERAT }\end{array}$ & & & TO & NILAI & 9 \\
\hline & $45-70$ & KUMUH SEDANG & & & TINGK & & TIDAK \\
\hline & $19-44$ & KUMUH RINGAN & & & & KuMu & КUMUH \\
\hline
\end{tabular}




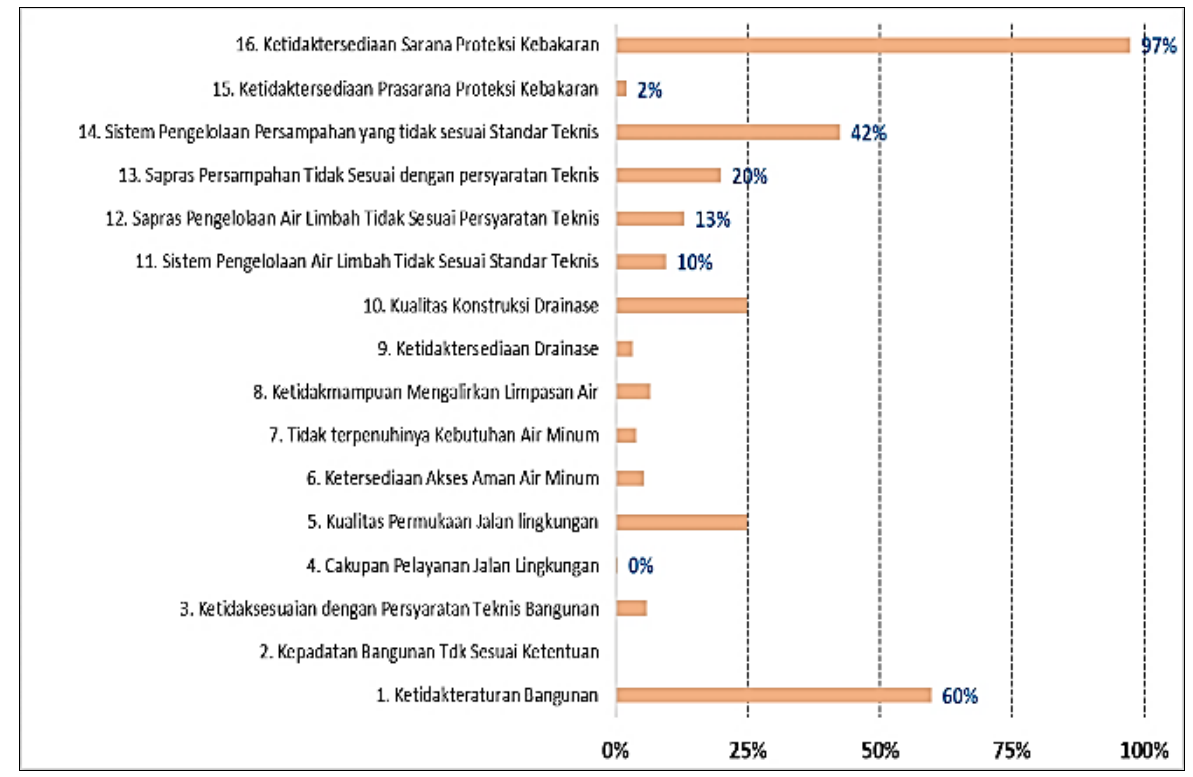

Gambar 2. Grafik Persentasi Tingkat Kekumuhan Awal berdasarkan 16 Parameter Kumuh

Tabel 3. Rekapitulasi Data Baseline Tingkat Kekumuhan Awal di Tingkat RT

\begin{tabular}{|c|c|c|c|c|c|c|}
\hline RT/RW/DUSUN & $\begin{array}{l}\text { Jumlah } \\
\text { Kepala } \\
\text { Rumah } \\
\text { Tangga }\end{array}$ & $\begin{array}{c}\text { Jumlah } \\
\text { Kepala } \\
\text { Keluarga }\end{array}$ & \begin{tabular}{|c|} 
Jumlah \\
Kepala \\
Rumah \\
Tangga MBR
\end{tabular} & $\begin{array}{c}\text { Jumlah } \\
\text { Bobot } \\
\text { Kekumuhan } \\
\text { Awal }\end{array}$ & $\begin{array}{l}\text { Tingkat Kekumuhan } \\
\text { Awal }\end{array}$ & SK/TERDUGA KUMUH \\
\hline RT009-RW003 & 46 & 46 & 17 & 6 & TIDAK KUMUH & TERDUGA \\
\hline RT010-RW004 & 58 & 62 & 0 & 15 & TIDAK KUMUH & TERDUGA \\
\hline RT011-RW004 & 47 & 48 & 10 & 10 & TIDAK KUMUH & TERDUGA \\
\hline RT012-RW004 & 22 & 26 & 0 & 11 & TIDAK KUMUH & TERDUGA \\
\hline RT013-RW004 & 52 & 61 & 4 & 10 & TIDAK KUMUH & TERDUGA \\
\hline RT014-RW004 & 57 & 61 & 0 & 15 & TIDAK KUMUH & TERDUGA \\
\hline RT015-RW005 & 27 & 27 & 0 & 6 & TIDAK KUMUH & TERDUGA \\
\hline RT016-RW005 & 40 & 41 & 2 & 10 & TIDAK KUMUH & TERDUGA \\
\hline RT017-RW005 & 38 & 39 & 0 & 8 & TIDAK KUMUH & TERDUGA \\
\hline RT018-RW005 & 55 & 55 & 30 & 5 & TIDAK KUMUH & TERDUGA \\
\hline RT019-RW005 & 56 & 69 & 0 & 5 & TIDAK KUMUH & TERDUGA \\
\hline RT020-RW006 & 31 & 32 & 31 & 30 & KUMUH RINGAN & TERDUGA \\
\hline RTO21-RWOO2 & 29 & 29 & 26 & 25 & KUMUH RINGAN & TERDUGA \\
\hline RTO22-RW006 & 77 & 77 & 40 & 15 & TIDAK KUMUH & TERDUGA \\
\hline RT023-RW006 & 65 & 77 & 49 & 15 & TIDAK KUMUH & TERDUGA \\
\hline RT024-RW006 & 55 & 55 & 46 & 8 & TIDAK KUMUH & TERDUGA \\
\hline RT025-RW007 & 57 & 59 & 24 & 20 & KUMUH RINGAN & TERDUGA \\
\hline RT026-RW007 & 26 & 29 & 17 & 14 & TIDAK KUMUH & TERDUGA \\
\hline RT027-RW007 & 30 & 30 & 0 & 6 & TIDAK KUMUH & TERDUGA \\
\hline RT028-RW007 & 24 & 27 & 6 & 10 & TIDAK KUMUH & TERDUGA \\
\hline RT029-RW008 & 86 & 88 & 0 & 16 & KUMUH RINGAN & TERDUGA \\
\hline RT030-RW008 & 89 & 107 & 8 & 13 & TIDAK KUMUH & TERDUGA \\
\hline RT031-RW003 & 44 & 45 & 20 & 25 & KUMUH RINGAN & TERDUGA \\
\hline RT032-RW007 & 26 & 30 & 2 & 10 & TIDAK KUMUH & TERDUGA \\
\hline RT033-RW006 & 41 & 43 & 7 & 23 & KUMUH RINGAN & TERDUGA \\
\hline RT034-RW002 & 43 & 45 & 13 & 24 & KUMUH RINGAN & TERDUGA \\
\hline RT035-RW007 & 62 & 62 & 44 & 20 & KUMUH RINGAN & TERDUGA \\
\hline RT036-RW008 & 50 & 50 & 0 & 11 & TIDAK KUMUH & TERDUGA \\
\hline RT037-RW002 & 45 & 45 & 41 & 36 & KUMUH RINGAN & TERDUGA \\
\hline RT001-RW001 & 36 & 36 & 8 & 10 & TIDAK KUMUH & TERDUGA \\
\hline RT002-RW001 & 31 & 31 & 2 & 10 & TIDAK KUMUH & TERDUGA \\
\hline RTOO3-RWOO3 & 65 & 78 & 63 & 36 & KUMUH RINGAN & TERDUGA \\
\hline RTO04-RWOO2 & 39 & 39 & 32 & 16 & KUMUH RINGAN & TERDUGA \\
\hline RT005-RW002 & 43 & 46 & 39 & 20 & KUMUH RINGAN & TERDUGA \\
\hline RTO06-RW002 & 34 & 38 & 33 & 45 & KUMUH SEDANG & TERDUGA \\
\hline RT007-RW003 & 42 & 43 & 30 & 21 & KUMUH RINGAN & TERDUGA \\
\hline RT008-RW003 & 37 & 44 & 18 & 10 & TIDAK KUMUH & TERDUGA \\
\hline 37 & 1705 & 1820 & & 9 & TIDAK KUMUH & \\
\hline
\end{tabular}

\section{Analisis Kekumuhan Akhir}

Setelah dilakukan investasi peningkatan kualitas lingkungan permukiman kumuh di Kelurahan Muara Bulian pada tahun 2020, maka diketahui data investasi output dan outcame pada lokasi kegiatan di RT031, RT003 dan RT006 dapat dilihat pada Tabel 4, Tabel 5 dan Tabel 6 berikut : 
Rioni Rizki Aldiansyah, Pengkatan Kualitas Permukiman Melalui Program Kotaku Di Kelurahan Muara Bulian

Tabel 4. Perhitungan tingkat kekumuhan RT.031

\begin{tabular}{|c|c|c|c|c|c|c|c|c|c|c|c|c|}
\hline \multicolumn{2}{|c|}{ PERHITUNGAN TINGKAT KEKUMUHAN } & \multicolumn{3}{|c|}{ RT031-RW003 } & \multirow{6}{*}{$\begin{array}{l}\mathrm{Ha} \\
\mathrm{Ha} \\
\text { Unit } \\
\text { Jiwa } \\
\text { KK }\end{array}$} & & & & & & & \\
\hline \multirow{5}{*}{$\begin{array}{l}\text { Provinsi } \\
\text { Kab/Kota } \\
\text { Kecamatan } \\
\text { Kawasan }\end{array}$} & : Jambi & \multicolumn{2}{|r|}{ Luas SK } & 1,22 & & & & & & & & \\
\hline & : Batanghari & \multicolumn{2}{|c|}{ Luas Verifikasi } & 1,22 & & & & & & & & \\
\hline & : Muara Buian & \multicolumn{2}{|c|}{ Jumlah Bangunan } & 44 & & & & & & & & \\
\hline & : Muara Bulian & \multicolumn{2}{|c|}{ Jumlah Penduduk } & 170 & & & & & & & & \\
\hline & & & & 45 & & & & & & & & \\
\hline \multirow{2}{*}{ ASPEK } & \multirow{2}{*}{ KRITERIA } & \multicolumn{4}{|c|}{ KONDISI AWAL (BASELINE) } & \multicolumn{3}{|c|}{$\begin{array}{l}\text { OUTPUT- OUTCOME } \\
\text { OUTPUT } \\
\end{array}$} & \multicolumn{4}{|c|}{ KONDISI AKHIR } \\
\hline & & NUMERIK & SATUAN & PROSEN (\%) & NILAI & INFRASTRUKTUR & VOLUME & SAT. & NUMERIK & SAT. & PROSEN & NILAI \\
\hline \multirow{3}{*}{$\begin{array}{l}\text { 1. KONDISI BANGUNAN } \\
\text { GEDUNG }\end{array}$} & a. Ketidakteraturan Bangunan & 43,00 & Unit & $97,73 \%$ & 5 & & & Unit & 43,00 & Unit & $97,73 \%$ & 5 \\
\hline & b. Kepadatan Bangunan & - & $\mathrm{Ha}$ & $0,00 \%$ & 0 & & & $\mathrm{Ha}$ & - & $\mathrm{Ha}$ & $0,00 \%$ & 0 \\
\hline & c. Ketidaksesuaian dengan Persy Teknis Bangunan & - & Unit & $0,00 \%$ & 0 & & & Unit & - & Unit & $0,00 \%$ & 0 \\
\hline \multicolumn{2}{|l|}{$\begin{array}{r}\text { Rata-rata Kondisi } \\
\text { Bangunan Gedung } \\
\end{array}$} & \multicolumn{4}{|c|}{$32,58 \%$} & & & & \multicolumn{4}{|c|}{$32,58 \%$} \\
\hline \multirow{2}{*}{$\begin{array}{l}\text { 2. Kondisi Jalan } \\
\text { Lingkungan }\end{array}$} & a. Cakupan Pelayanan Jalan Lingkungan & - & Meter & $0,00 \%$ & 0 & & & Meter & - & Meter & $0,00 \%$ & 0 \\
\hline & b. Kualitas Permukaan Jalan lingkungan & 575,70 & Meter & $100,00 \%$ & 5 & $\begin{array}{c}\begin{array}{c}\text { Peningkatan } \\
\text { alan }\end{array} \\
\end{array}$ & 397 & Meter & 178,70 & Meter & $31,04 \%$ & 1 \\
\hline \multicolumn{2}{|l|}{$\begin{array}{r}\text { Rata-rata Kondisi Jalan } \\
\text { Lingkungan }\end{array}$} & \multicolumn{4}{|c|}{$50,00 \%$} & & & & \multicolumn{4}{|c|}{$15,52 \%$} \\
\hline \multirow{2}{*}{$\begin{array}{l}\text { 3. Kondisi Penyediaan Air } \\
\text { Minum }\end{array}$} & a. Ketersediaan Akses Aman Air Minum & 1,00 & KK & $2,22 \%$ & 0 & & & KK & 1,00 & KK & $2,22 \%$ & 0 \\
\hline & b. Tidak terpenuhinya Kebutuhan Air Minum & - & KK & $0,00 \%$ & 0 & & & KK & - & KK & $0,00 \%$ & 0 \\
\hline \multicolumn{2}{|l|}{$\begin{array}{r}\text { Rata-rata Kondisi } \\
\text { Penyediaan Air Minum } \\
\end{array}$} & \multicolumn{4}{|c|}{$0,00 \%$} & & & & \multicolumn{4}{|c|}{$0,00 \%$} \\
\hline & a. Ketidakmampuan Mengalirkan Limpasan Air & - & $\mathrm{Ha}$ & $0,00 \%$ & 0 & & & $\mathrm{Ha}$ & - & $\mathrm{Ha}$ & $0,00 \%$ & 0 \\
\hline $\begin{array}{l}\text { 4. Kondisi Drainase } \\
\text { Lingkungan }\end{array}$ & b. Ketidaktersediaan Drainase & - & Meter & $0,00 \%$ & 0 & & & Meter & - & Meter & $0,00 \%$ & 0 \\
\hline & c. Kualitas Konstruksi Drainase & 287,85 & Meter & $100,00 \%$ & 5 & & & Meter & 287,85 & Meter & $100,00 \%$ & 5 \\
\hline $\begin{array}{r}\text { Rata-rata Kondisi Drainase } \\
\text { Lingkungan }\end{array}$ & & & & $20,00 \%$ & & & & & & & $20,00 \%$ & \\
\hline 5. Kondisi Pengelolaan Air & $\begin{array}{l}\text { a. Sistem Pengelolaan Air Limbah Tidak Sesuai } \\
\text { Standar Teknis }\end{array}$ & & KK & $0,00 \%$ & 0 & & & KK & - & KK & $0,00 \%$ & 0 \\
\hline Limbah & \begin{tabular}{|l|} 
b. Prasarana dan Sarana Pengelolaan Air Limbah \\
Tidak Sesuai dengan Persyaratan Teknis
\end{tabular} & - & KK & $0,00 \%$ & 0 & & & KK & - & KK & $0,00 \%$ & 0 \\
\hline $\begin{array}{l}\text { Rata-rata Kondisi } \\
\text { Penyediaan Air Limbah }\end{array}$ & & & & $0,00 \%$ & & & & & & & $0,00 \%$ & \\
\hline 6. Kondisi Pengelolaan & $\begin{array}{l}\text { a. Prasarana dan Sarana Persampahan Tidak Sesuai } \\
\text { dengan persyaratan Teknis } \\
\end{array}$ & - & KK & $0,00 \%$ & 0 & & & KK & - & KK & $0,00 \%$ & 0 \\
\hline Persampahan & $\begin{array}{l}\text { b. Sistem Pengelolaan Persampahan yang tidak } \\
\text { sesuai Standar Teknis }\end{array}$ & 45,00 & KK & $100,00 \%$ & 5 & & & KK & 45,00 & KK & $100,00 \%$ & 5 \\
\hline $\begin{array}{r}\text { Rata-rata Kondisi } \\
\text { Pengelolaan }\end{array}$ & & & & $33,33 \%$ & & & & & & & $33,33 \%$ & \\
\hline 7. Kondisi Proteksi & a. Ketidaktersediaan Prasarana Proteksi Kebakaran & - & Unit & $0,00 \%$ & 0 & & & Unit & - & Unit & $0,00 \%$ & 0 \\
\hline Kebakaran & b. Ketidaktersediaan Sarana Proteksi Kebakaran & 44,00 & Unit & $100,00 \%$ & 5 & & & Unit & 44,00 & Unit & $100,00 \%$ & 5 \\
\hline $\begin{array}{r}\text { Rata-rata Kondisi Proteksi } \\
\text { Kebakaran }\end{array}$ & & & & $50,00 \%$ & & & & & & & $50,00 \%$ & \\
\hline & $\begin{array}{l}\text { BATAS AMBANG NILAI TINGKAT KEKUMUHAN } \\
60-80 \text { : KUMUH BERAT }\end{array}$ & & & AL NILAI & 25 & & & & & TOTAL & NILAI & 21 \\
\hline & 38- 59: KUMUH SEDANG & & TINGKATK & KEKUMUHAN & KUMUH & & & & & TINGKATKI & KUMUHAN & KUMUH \\
\hline & $16-37$ : KUMUH RINGAN & & IINGKATK & KEKUIVUHAN & RINGAN & & & & & ПINGKAIK K- & KUIVIUAAN & RINGAN \\
\hline & $<16$, DINYATAKAN TIDAK KUMUH & & A2 KEKUMUH & HAN SEKTORAL & $26,56 \%$ & & & & RATA2 K & ERUMUHA & SEKTORAL & $21,63 \%$ \\
\hline & & & KONTRIBUSI & PENANGANAN & $0,00 \%$ & & & & & TRIBUSI PEI & IANGANAN & $18,55 \%$ \\
\hline
\end{tabular}


Rioni Rizki Aldiansyah, Pengkatan Kualitas Permukiman Melalui Program Kotaku Di Kelurahan Muara Bulian

Tabel 5. Perhitungan tingkat kekumuhan RT.003

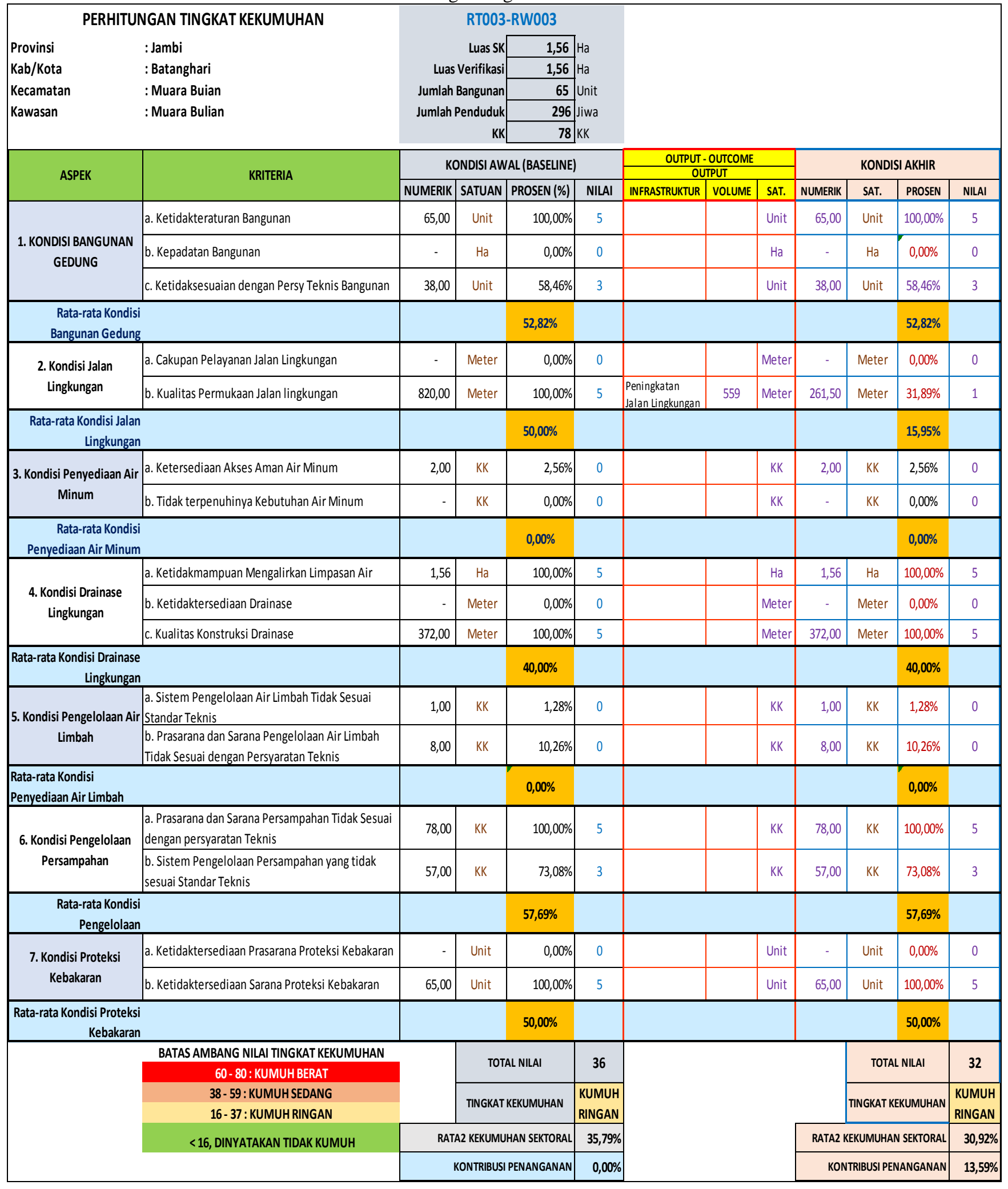


Tabel 6. Perhitungan tingkat kekumuhan RT.006

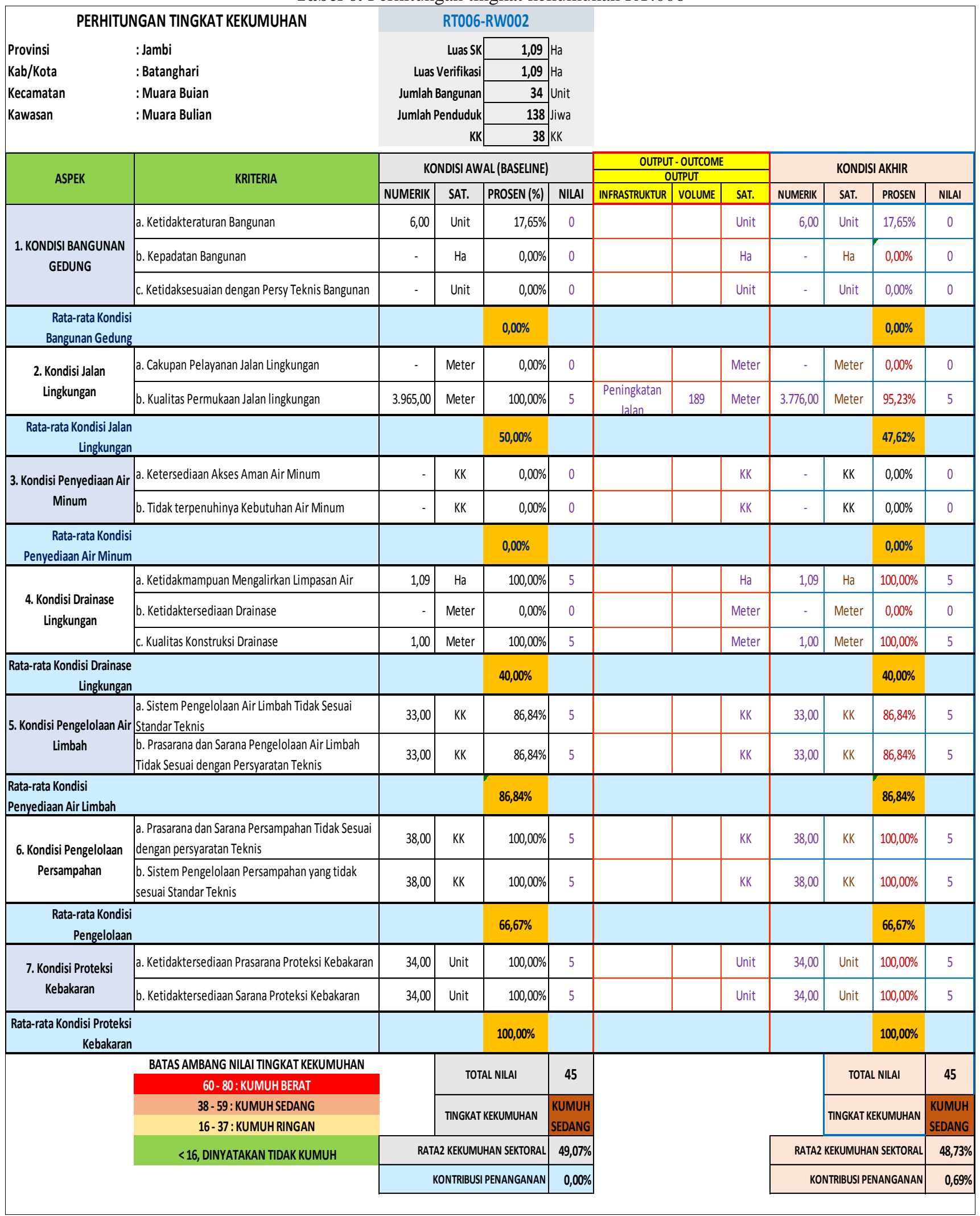

Dengan hasil pengolahan tingkat kekumuhan akhir maka dapat disimpulkan bahwa pada RT031 memberikan kontribusi penanganan sebesar 18,55 \%, RT003 memberikan kontribusi penanganan sebesar 13,59 \% dan RT006 memberikan kontribusi penanganan sebesar 0,69\%. Sesuai dengan batas ambang nilai tingkat kekumuhan 71-95 kumuh berat, 45-70 kumuh sedang, 19-44 kumuh ringan dan <19 dinyatakan tidak kumuh (Permen PU-PR No 14 Tahun 2018). Rekapitulasi pengurangan kumuh pada tingkatan kelurahan dapat dilihat pada Tabel 2 dan pada Gambar 2 yang disajikan. Setelah itu kita dapat melihat capaian penanganan peningkatan kualitas permukiman kumuh pada Tabel 7 berikut: 
Tabel 7. Kesimpulan Capaian Penanganan Permukiman Kumuh

\begin{tabular}{|c|l|c|c|c|c|}
\hline No & \multicolumn{1}{|c|}{ URAIAN } & $\begin{array}{c}\text { KONDISI AWAL } \\
\text { (BASELINE) }\end{array}$ & $\begin{array}{c}\text { JENIS } \\
\text { INFRASTRUKTUR } \\
\text { TERBANGUN }\end{array}$ & KONDISI AKHIR & $\begin{array}{c}\text { CAPAIAN } \\
\text { PENANGANAN }\end{array}$ \\
\hline 1 & Luas Kumuh (Ha) & 82,89 & & 79.02 & 3.87 \\
\hline 2 & Nilai Skoring & 9 & \multirow{2}{*}{ Jalan Lingkungan } & TIDAK KUMUH & $\begin{array}{c}\text { Kekumuhan } \\
\text { Menjadi Nol }\end{array}$ \\
\cline { 1 - 2 } 3 & Tingkat Kekumuhan & TIDAK KUMUH & &
\end{tabular}

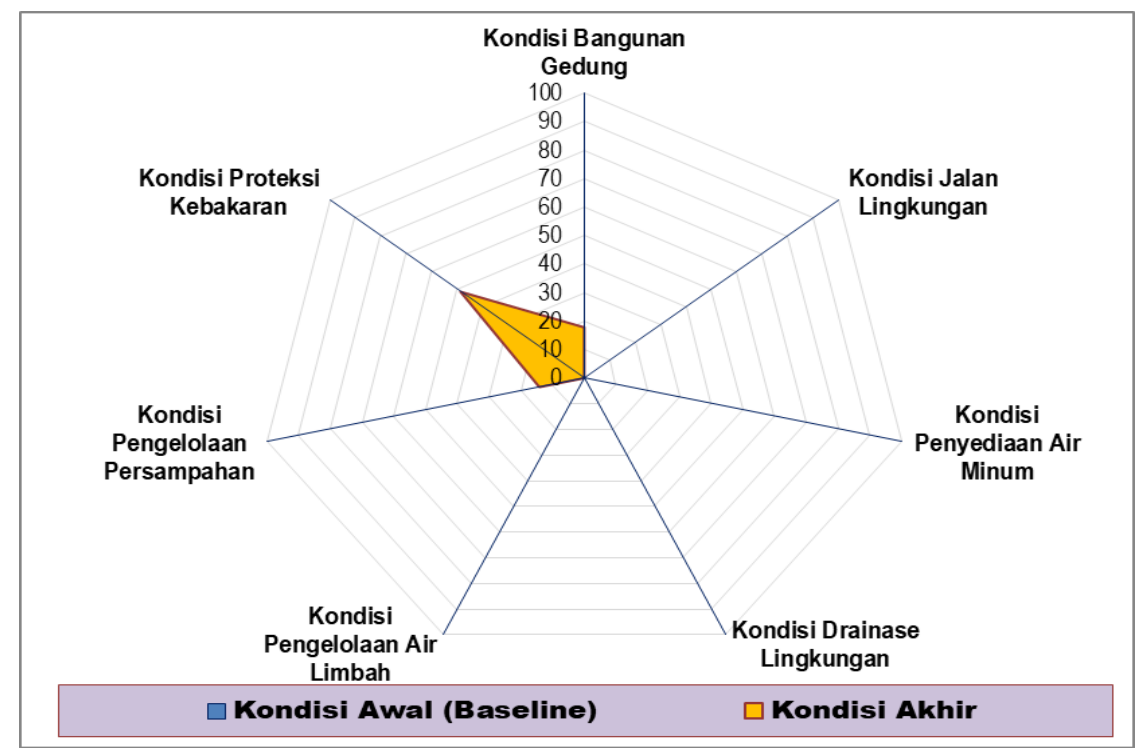

Gambar 2. Grafik Spider Web Kondisi Awal dan Kondisi Akhir Kumuh

\section{SIMPULAN}

Dalam penelitian ini dapat disimpulkan bahwa faktor fisik dan non fisik dalam sangat berpengaruh terhadap tingkat kekumuhan di kelurahan Muara Bulian Kabupaten Batanghari. Dari hasil rekapitulasi hasil pendataan baseline menggunakan panduan yang sudah ditetapkan pada Permen Pu No.14 Tahun 2018. Maka juga dapat disimpulkan bahwa tidak semua RT yang terduga kumuh, jika dirunut berdasarkan hasil baseline ada 14 RT diduga kumuh ringan dan 1 RT kumuh sedang dari total 37 RT di kelurahan Muara Bulian. Sehingga dari data tersebut pendanaan melalui dana BPM Program Kotaku tahun 2020 hanya melakukan investasi pengurungan kumuh pada 3 lokasi RT saja yaitu pada RT031 dengan nilai Kumuh Ringan memberikan kontribusi penanganan sebesar 18,55 \%, RT003 Kumuh Ringan memberikan kontribusi penanganan sebesar 13,59 \%, dan RT006 Kumuh Sedang memberikan kontribusi penanganan sebesar 0,69\%. Dalam hal ini kegiatan investasi pengurangan kumuh pada tahun 2020 dilakukan dengan pekerjaan pembuatan jalan rigid beton sepanjang 1145 Meter.

Dari hasil pendataan dan investasi yang sudah dikerjakan belum menyelesaikan permasalahan permukiman kumuh pada kelurahan mura bulian. Maka perlu di inventarisir lebih lanjut guna menyelesaikan secara komprehensif pada lokasi-lokasi yang sudah di urut sesuai dengan parameter kekumuhannya.

\section{DAFTAR PUSTAKA}

DSN Ridwan, 2020, Peningkatan Kualitas Permukiman Desa Labuapi Kabupaten Lombok Barat Menuju Program Kotaku 2020, Lombok Barat

Kurniawan N, 2019, Strategi Perencanaan Infrastruktur Menuju Kota Tanpa Kumuh (Studi kasus : Program Kotaku 2019 Gerung Selatan Kabupaten Lombok Barat), Lombok Barat

Undang Undang Republik Indonesia Nomor 1 Tahun 2011 Tentang Perumahan dan Kawasan Permukiman, Jakarta

Undang Undang Republik Indonesia Nomor 4 Tahun 1992 Tentang Perumahan dan Permukiman, Jakarta

Peraturan Menteri Pekerjaan Umum dan Perumahan Rakyat Republik Indonesia Nomor 14/PRT/M/2018 Tentang

Pencegahan dan Peningkatan Kualitas Terhadap Perumahan Kumuh dan Permukiman Kumuh, Jakarta

Keputusan Menteri Permukiman dan Prasarana Wilayah Republik Indonesia Nomor 217/KPTS/M/2002 Tentang Pedoman Umum Peningkatan Kualitas Permukiman, Jakarta

Keputusan Bupati Batanghari Nomor: 110 Tahun 2019 Tentang Penetapan Lokasi Lingkungan Perumahan dan Permukiman Kumuh Di Kabupaten Batanghari, Jambi

Badan Pusat Statistik Kabupaten Batanghari, 2019, Kabuoaten Batang Hari dalam Angka, Batang hari 